University of California, Hastings College of the Law UC Hastings Scholarship Repository

Faculty Scholarship

1998

\title{
Sentencing in England: The Rise of Populist Punishment
}

Aaron J. Rappaport

UC Hastings College of the Law, rappapor@uchastings.edu

Follow this and additional works at: http://repository.uchastings.edu/faculty_scholarship

Part of the Criminal Law Commons, and the Criminal Procedure Commons

\section{Recommended Citation}

Aaron J. Rappaport, Sentencing in England: The Rise of Populist Punishment, 10 Fed. Sent. R. 247 (1998).

Available at: http://repository.uchastings.edu/faculty_scholarship/661

This Article is brought to you for free and open access by UC Hastings Scholarship Repository. It has been accepted for inclusion in Faculty Scholarship

by an authorized administrator of UC Hastings Scholarship Repository. For more information, please contact marcusc@uchastings.edu. 


\title{
Faculty Publications \\ UC Hastings College of the Law Library
}

\author{
Author: Aaron J. Rappaport \\ Source: $\quad$ Federal Sentencing Reporter \\ Citation: $\quad 10$ Fed. Sent. R. 247 (1998). \\ Title: $\quad$ Sentencing in England: The Rise of Populist Punishment
}

Originally published in FEDERAL SENTENCING REPORTER. This article is reprinted with permission from FEDERAL SENTENCING REPORTER and University of California Press; Vera Institute of Justice. 


\section{EDITOR'SOBSERVATIONS}

\section{Sentencing in England: The Rise of Populist Punishment}

\section{AARON J. RAPPAPORT}

Assistant Professor, University of California, Hastings College of the Law $\rightarrow$

$\mathrm{I}$ $\mathrm{n}$ the early 1990 s, while law makers in the United States were gripped by a law and order fervor, the British Government embarked on a dramatically different kind of sentencing experiment. The criminal legislation enacted by Parliament in I99I was the crowning achievement of that venture: It deemphasized the use of incarceration for nonviolent and non-sexual offenders, called for greater use of community penalties, and appeared to enshrine just deserts as a guiding principle of punishment. Some proponents of these changes thought, or at least hoped, that the initiatives would mark the beginning of a new and enlightened period of penal policy in England.

The story of how this remarkable experiment came about, and how it has been eroded by a wave of public pressure for tougher sentences, is the focus of this Issue. For American sentencing reformers, who are facing a law and order tide at least as strong as that faced in England, this is a cautionary and sobering tale. It is a tale, ultimately, that raises fundamental questions about the ability of any Western nation, under the pressures of mass culture and public opinion, to engage in a rational debate about criminal punishment.

\section{Background: The Bar and the Bench}

The English sentencing system is, at once, both familiar and foreign to the American observer. It is, from one perspective, reminiscent of the American system of two decades ago. With several notable and recent exceptions, English judges continue to wield broad and largely unstructured discretion in sentencing matters, limited by few constraints apart from expansive statutory maxima and minima.

Beneath this surface familiarity, however, lies more foreign terrain. Some of the distinctive features of the English system are discussed in two introductory pieces by Maimon Schwarzschild and D.A. Thomas. Schwarzschild's article examines the cultural peculiarities and unwritten rules of the English legal profession - and how these conditions have influenced sentencing practices. Much of what makes the English system unique can be attributed to the common upbringing, schooling, and class background of the English barristers and judges. Not only has a common upper-crust outlook permitted greater consistency in sentencing decisions, but it has allowed the Bar and the Bench to maintain a degree of insulation from mainstream culture and public opinion. Schwarzschild concludes with some reflections on whether this insularity can be preserved in light of emerging changes in the legal professions.

D.A. Thomas's article examines the role of the Court of Appeal in the English sentencing system. Although the House of Lords can, in theory, review sentencing decisions, the Court of Appeal is for all intents and purposes the highest sentencing court in the land. Unlike the American system, where a law of sentencing emerged only after the passage of the Sentencing Reform Act of 1984 , the Court of Appeal has tried since the early I970s to develop what can only be described as a common law of sentencing. Its "guideline cases" provide the lower Crown Courts with guidance on the appropriate punishment range and the relevant factors for consideration when sentencing offenders for a select number of crimes. These guideline decisions offer a fascinating counterpoint to the rulings of the U.S. Sentencing Commission. Three illustrative Court of Appeal cases are reprinted at the end of this Issue. 


\section{...the edifice erected by the} 1991 Act was dismantled within a few years of its

passage...
These introductory articles paint a picture of the English judiciary that, at least until recently, has enjoyed broad independence in sentencing matters, both in terms of its relative autonomy from legislative control and its insularity from public opinion. One might have anticipated that, from this starting point, England would have pursued a different trajectory in sentencing matters relative to its American cousins - one that left greater discretion and responsibility with the judiciary. During the late i 980 and early i990s, that prediction seemed borne out, as English lawmakers sought to construct a unique sort of sentencing structure.

\section{The Criminal Justice Act 1991}

During the late 1980 s, as American lawmakers rushed to implement mandatory minimum sentences and binding sentencing guidelines, English policymakers were beginning to doubt the wisdom of a strictly punitive approach to crime. Various trends - a burgeoning prison population, well-publicized prison riots, a government committed to fiscal conservatism - eventually culminated in Parliament's passage of the Criminal Justice Act I99I. It was a landmark piece of legislation. As Andrew Ashworth observed after its passage: "In terms of changing the direction of sentencing, [the Act] is certainly the most important such statute since I948, and perhaps the most important of the century."

Two features of the Act were particularly notable. One was the Act's desire to expand the use of community penalties and reduce the courts' emphasis on incarceration for certain offenders. The Act addressed the former goal by creating new types of community sanctions - such as the curfew and the combination order - and by deeming these sanctions punitive, rather than rehabilitative, in nature. At the same time, the Act sought to narrow the use of incarceration by creating a presumption - a custody threshold - against the imposition of a prison term. Incarceration was permitted only where the offense was so "serious that only [a custodial sentence] can be justified." Although the Act also qualified the "seriousness" standard by permitting incarceration for sexual and violent offenders in other circumstances, this exception appeared narrowly drawn and was limited to cases where incarceration alone "would be adequate to protect the public from serious harm."

A second notable feature of the Act was its philosophical orientation: It sought to establish "just deserts" as a dominant aim of punishment. ${ }^{2}$ One illustration of this orientation was the requirement that punishment be "commensurate with the seriousness of the offense." By adopting the concept of commensurability, Parliament was thought to have signalled its preference for a desert-based principle of punishment. ${ }^{3}$ Other provisions, which restricted the courts' consideration of an offender's criminal record, further illustrated the desert-based ethos of the Act. Notably, section 29 of the Act limited the Court's authority under certain circumstances to consider an offender's prior record when imposing a sentence. Another provision, deemed the "two offense rule," limited the number of offenses that a court could take into consideration when deciding whether the custody threshold had been satisfied. These provisions conflicted with incapacitative theories of punishment, which typically treat an extensive criminal record as a sig. nificant indicator of recidivism risk. ${ }^{4}$ But they appeared to be consistent with at least some versions of just desert theory, which dictate that punishment should reflect the seriousness of an offender's crime of conviction and should not be increased significantly for prior or related crimes.

\section{Reaction and Reversal}

For all its promise, the I99I Act never had the impact on English sentencing its proponents had hoped for. As George Mair and Estella Baker argue in their articles, the edifice erected by the I991 Act was dismantled within a few years of its passage.

George Mair observes that the Act's attempt to expand the use of community sanctions has largely failed. According to Mair, community sanctions have become marginalized in the I990s and have been increasingly used for low level offenders, rather than as true substitutes for incarceration. At the same time, prison populations have increased dramatically - growing from 43,000 to 63,700 between 1992 and 1997. Mair attributes a significant part of this growth to the shift in public opinion towards increased punitiveness, and to the judiciary's responsiveness to that shift. Reviewing the political landscape, Mair sees little reason to believe that the punitive trend will end anytime soon, and he concludes: "the outlook for a more enlightened approach to community penalties looks bleak." 
Estella Baker views the changes in English policy in terms of an evolution of penal philosophy. She argues that the English system has begun to drift from the desert-based ethos that underlay the I99I Act to an ethos characterized by "protectionism." As she notes, the first steps towards protectionism occurred with the passage of the Criminal Justice Act of 1993, which watered down Section 29 and repealed the "two offense rule." The pace of change has, if anything, increased in recent years, with the introduction of several protectionist initiatives, including the Sexual Offenders Act of 1997, the Crime (Sentences) Act 1997 and the pending Crime and Disorder Bill. Like Mair, Baker attributes the shift in English penal policy, in large part, to the general politicization of sentencing issues in England. Her prognosis is equally blunt: "[T]he available indications are that the trend towards protectionism will continue...."

In his article, Andrew Ashworth examines one of these recent protectionist bills - the Crime (Sentences) Act I997. The Act creates mandatory penalties for offenders convicted of a third Class A drug trafficking offense or a third residential burglary offense - the first significant mandatory penalties in modern English history. Their adoption, according to Ashworth, constitutes a defining moment in the battle between Parliament and the Judiciary over sentencing.

Until quite recently, Parliament's interference in sentencing matters has been limited. Even the 1991 Act, which established a broad legislative framework for sentencing, left significant discretion to the judges (although the courts bristled against even these minor encroachments). ${ }^{6}$ By enacting the Crime (Sentences) Act, however, Parliament demonstrated a far greater willingness to intrude on matters traditionally left to the judiciary. Not surprisingly, the judiciary greeted the bill with hostility.7 Although unable to defeat the legislation entirely, a coalition of judges and Bishops succeeded in amending the bill in the House of Lords to permit courts to ignore the mandatory sentences in certain limited circumstances. The scope and significance of this exception is uncertain. It is notable, nonetheless, that the only legislative entity able to muster any resistance to the public's clamor for tougher penalties was the one body - the House of Lords - that remains largely insulated from electoral pressure.

Susan Rex and Andrew von Hirsch's article offers some final observations on the role of community penalties in the English sentencing system. The article can be seen as a reflection on the relationship between two key elements of the I99I Act-its philosophical orientation towards just deserts and its policy emphasis on community penalties. Rex and von Hirsch contend that there is no theoretical obstacle to incorporating community penalties into a just desert framework. They suggest that community sanctions can be accurately measured along a common "sentencing severity scale," which they outline in their paper. What the authors cannot predict is whether community penalties or just deserts can again find favor among a British citizenry that is increasingly calling for punitive and protectionist legislation.

\section{Public Opinion and English Sentencing}

As this overview of recent developments in English sentencing law highlights, public opinion has played a critical role in the movement towards more punitive sentences, mandatory penalties, and protectionist legislation. Perhaps the most extraordinary part of this transformation has been the influence of public opinion on judicial decisionmaking itself. As Andrew Ashworth and George Mair both observe, prison populations increased dramatically from 1993 through 1997 - even before the recent wave of protectionist legislation. During this period, Ashworth notes, judges allowed sentences to be "talked up" by politicians and the media. ${ }^{8}$ This development raises fundamental questions about the legitimate role of public opinion in judicial decisionmaking. What, in short, is the proper jurisprudential significance of public opinion?

That question is precisely the topic of Stephen Shute's contribution. Shute notes that some jurists and theorists are skeptical of giving weight to public opinion in sentencing decisions. Some contend that courts should be wholly insulated from public pressures; others question whether public opinion can provide a principled basis for sentencing decisions. Shute observes that, despite this criticism, courts in England continue to cite
By enacting the Crime (Sentences)

Act, Parliament demonstrated a

far greater willingness to intrude

on matters traditionally left to

the judiciary. 


\section{Is it possible to carve out} some space from

the storm of public passions

within which a rational

sentencing debate can

emerge? public opinion as a valid consideration when imposing a sentence, although the precise role of this factor in their decisions remains ill-defined. His article raises provocative questions for American scholars and jurists, who confront similar questions about the relationship between public opinion and criminal justice.

Public opinion has played a similar part in the passage of recent sentencing legislation, such as the Crime (Sentences) Act I997. This may not be particularly controversial in theory, as citizens typically expect the Government to respond to their needs and desires. Nonetheless, questions remain about the wisdom of using public opinion as a guide to policy. In their submission, Julian Roberts and Mike Hough report on a recent survey they conducted regarding public attitudes towards crime and punishment. Consistent with opinion surveys in other nations, their findings show that the public tends to both overestimate the rate of increase in crime and underestimate the punitiveness of the sentencing system. Although public opinion certainly cannot be ignored entirely, the survey raises serious questions about relying uncritically on public opinion in sentencing matters.

\section{Sentencing Policy in the Age of Populism}

Britain, of course, is not the only Western nation experiencing a populist backlash against crime. American readers will surely be familiar with a similar trend in their own country - one that has also led to increasingly punitive sentences and the enactment of a range of mandatory sentences. Is there some element shared by both nations that generates such powerful public sentiments about crime? Perhaps it has something to do with the advances of modern telecommunications, which amplifies the power of the media and makes crime seem more immediate and pervasive. Or perhaps it is related to the economic dislocations caused by the free-market, which erodes fixed traditions and customs that provide citizens with a sense of social order. Whatever the reason, there seems little reason to believe that the power of public opinion over crime policy will dissipate soon in either country.

Given the concerns already raised about the utility of public opinion as a guide to policy, one might wonder whether it is possible to carve out some space from the storm of public passions within which a rational sentencing debate can emerge. Julian Roberts and Michael Hough suggest that public education is one possible solution to this challenge. Such an effort is needed, they argue, to "counterbalance" the distorting impact of the media and to help the public become "more sagacious critics of the criminal justice system." Nonetheless, while this initiative should certainly be attempted, one might be skeptical that it will achieve significant success. As Hough and Roberts acknowledge, certain features of popular culture make it extremely difficult for the public to have an educated view of crime. Among other things, the media has little interest in providing a balanced account: "Erratic court decisions - especially those that are erratically lenient - are newsworthy; sensible decisions are not." 9 In the battle between the tabloid press and a public education campaign, one might be forgiven for betting on the former to win the day.

A second possible approach might be to develop innovative institutional arrangements to filter or refine public opinion in order to translate it into effective policies. The creation of the U.S. Sentencing Commission was rooted, in part, in the desire to create an expert body that could conduct dispassionate analysis of sentencing policy with some degree of insulation from public sentiments. The jury is still out on whether the Commission has succeeded in this regard, but recent history does not give much cause for optimism. Part of the problem is that the Commission is subservient to legislature powers and thus remains sensitive to both formal and informal Congressional - and hence, public - pressures.

Conceivably, other institutional structures might prove more effective in insulating decisionmaking from public opinion. D.A. Thomas, for example, observes that legislation pending before Parliament would establish a Sentencing Advisory Council to assist the judiciary in developing guideline decisions. Whether a greater judicial role in developing sentencing guidelines would be an improvement over the American model remains to be seen. However, it seems clear that, so long as the legislature retains the final say over sentencing matters, the public will be able to influence the direction of penal policy under either system.

A third and final approach would be to place limits on the ability of the legislature itself to translate public opinion into public policy. This approach is rarely discussed by American theorists, in part because it can be achieved only through constitutional reform, which faces nearly 
insurmountable obstacles under U.S. law. Nonetheless, constitutional reform is very much at issue in England today, where questions regarding the structure of the Parliament, the powers of the judiciary, the need for a Bill of Rights, and the relationship between English and European law are matters of significant public discussion. ${ }^{\circ}$

The current debate over crime policy underscores the importance, when making any constitutional change, to be cognizant of the need to maintain some distance between public opinion and government action. The U.S. Constitution offers one approach to this challenge: It seeks to tame majority opinion through several mechanisms, most notably through an effective Separation of Powers. By diffusing legislative power broadly, the U.S. Constitution hinders somewhat the ability of a majority to take control of the levers of government.

Many have observed that the Separations of Powers is far weaker-indeed, some say virtually non-existent - in England. What is more, the few mechanisms that today provide government institutions with some insulation from public opinion are under threat. The House of Lords, for example, is one of the only countermajoritarian institutions in England, which may explain why it was one of the few voices of caution during the debate over the Crime (Sentences) Act. But the House of Lords has been increasingly marginalized, and proposals have been made to subject the House to electoral control. Although lacking the American power of judicial review, the judiciary has also enjoyed a fair degree of independence from public opinion, cultivated by its elite background, insularity and the force of tradition. However, Maimon Schwarzschild observes that even these features are now under siege from a broad populist movement in England, and may soon be largely eroded."

As the constitutional debate unfolds, one can only hope that English lawmakers recognize the importance of maintaining within its government structure some insulation from untrammeled public opinion. If it fails to do so, if it fails to create some bulwark against majority passions, Britain may find itself even more susceptible than America to the populist trend in the law of sentencing. That would be a great shame for Britain, and for the cause of criminal justice as well.

\section{Notes}

${ }^{1}$ Andrew Ashworth, The Criminal Justice Act 1991, in Sentencing, Judicial Discretion and TRaining 77 (Colin Munro \& Martin Wasik, eds. 1992).

2 See Andrew Ashworth, supra note 1, at 84 ("the leading aim of English sentencing under the 1991 Act is ... proportionality" or "just deserts"). See also Andrew Ashworth, Sentencing Purposes in England, 3 FED. SENT. R. 337 (1991).

${ }^{3}$ Andew Ashworth, Legislature vs. Judiciary: The Struggle for Supremacy in English Sentencing, 10 FED. SENT. R. 275-277 (1998)

${ }^{4}$ See, e.g., Barbara M. Vincent, So What's the Purpose?, 9 FEd. SENT. R. 189 (1997).

${ }^{5}$ As Ashworth observes, the judiciary may have contributed to this transition by reading the principle of deterrence back into the custody and commensurability standards of the Act. See Ashworth, supra note 3, at 275 (citing Cunningham (1993) 14 Cr. App. R. (S) 444).

${ }^{6}$ See Andrew Ashworth, Sentencing Purposes in England, 3 FED. SENT. R. 337 (1991).

${ }^{7}$ For example, during the debate on the bill in the House of Lords, Lord Woolf declared that the bill, is a departure from our traditions. It sets a precedent which, once established, will undoubtedly be followed by further interventions in the future. It involves the legislature taking over what has hitherto always been accepted to be the proper role of the judiciary. In this country we have no written constitution. Our liberties have been protected by a careful constitutional balance between the different arms of government. The executive, the legislature and the judiciary are usually sensitive in not trespassing upon each other's role. That sensitivity involves self-restraint. So long as there is restraint, the protection which a written constitution would provide is less necessary in this country than in other parts of the globe. One of the regrettable features of the Bill is the way in which the legislature is interfering with what in the past was never doubted to be a judicial function.

House of Lords Debates, Jan. 27, 1998. The Lord Chief Justice of England, Lord Bingham of Cornhill, added that, "if as the century and the millennium slide to a close, our penal thinking is to be judged by the thinking that animates this Bill, than I for one will shrink from the judgment of history." See D.A. Thomas, The Crime(Sentences) Act of 1997, [1988] CRIM. L. REV. 83.

8 This point was expressly acknowledged by the Lord Chief Justice, who stated that, "the increase in prison population is not explained by any recent increase in sentencing powers, and I have no doubt that it is related to the pressure of public opinion." See Julian Roberts and Michael Hough, Public Attitudes Towards Sentencing in Britain, 10 Fed. SENT. R. 291-295 (1998).

9 Julian Roberts and Michael Hough, supra note 8. Hough and Roberts might have added that legislatures tend to overreact to public fears, as politicians strive to demonstrate their responsiveness to their constituencies' concerns. The U.S. Congress' efforts to enact mandatory sentences for crack cocaine following Len Bias' death from a cocaine overdose is a classic example. What makes this example particularly notable is that Bias actually died from an overdose of powder cocaine, not crack. 
${ }^{10}$ The broad scope of this debate can be seen by surveying some of the recent articles in THE Economist magazine. See, e.g., The House of Lords: Riddle in Ermine, THE ECONOMIST, Jan. 10, 1998 (discussing proposals to eliminate hereditary peers); Fudging British Rights, The Economist, Oct. 25, 1997 (assessing the incorporation of European charter into law); $A$ Survey of Britain's New Politics: The Great Debate-Power and the People, The Economist, Sept. 21, 1996 (arguing that power has become excessively concentrated within the cabinet); The Case for Reform, THE EconomIST, October 14, 1995 (discussing pressing need for constitutional reform).

"On a more positive note, Schwarzschild also predicts the emergence of greater judicial activism in England, and "even some judicial review along the lines familiar in America." He states that "European charters of rights, like the European Human Rights Convention, and various British laws as well," could serve as the basis for this judicial authority. See Maimon Schwarzschild, The English Legal Professions: An Indeterminate Sentence, 10 FEo. SENT. R. 253.258(1998), 